\title{
TECHNOLOGICAL INFRASTRUCTURE OF AGRICULTURE IN PROVIDING ECONOMIC GROWTH OF THE AGRARIAN SECTOR
}

Airat A. Zamaidinov ${ }^{1}$

Asiya K. Subaeva ${ }^{2}$

\begin{abstract}
The purpose of the study is to provide a scientific justification for the advancement of technological infrastructure and development of practical recommendations for improving the level of economic

production processes. The article proposes directions for supporting measures to lease agricultural machinery of a new generation that is distinguished by high technical and economic indicators, both in cash and in kind.
\end{abstract} efficiency of technical support for the agrarian sector of the national economy.The paper examines the theoretical foundations of the technological infrastructure of agriculture in ensuring economic growth of the agricultural sector. The structure of the production assets of the agricultural complex is analyzed. The actual and significant in modern conditions, the problem of deteriorating technical support system in the country is considered. The main advantage of the study is identification of a system of machines providing for a comprehensive mechanization and automation of

Keywords: fixed assets, material and technical base, capital-labor ratio, economic efficiency, resource-saving, process upgrading, technological capacity.

\section{INTRODUCTION}

Production facilities determine the economic potential of agricultural producers, since they represent a combination of basic and current assets of the enterprise. Fixed assets take the most of the material and technical base of agricultural enterprises, they are

\footnotetext{
${ }^{1}$ Kazan Federal University in Chistopol, 422980, Chistopol, Studencheskaya str, 15.

${ }^{2}$ Federal State Budgetary Educational Institution of Higher Education Ulyanovsk State Agricultural Academy named after P.A. Stolypin,432017, Ulyanovsk,bul'var Novyj Venec, 1
} 
repeatedly used in the production process and at the same time do not change their form, and gradually transmit their value to newly manufactured products. Machines and equipment are considered to be an active part of an enterprise's facilities and include: vehicles, machine and tractor fleet and combined harvester fleet, material-working agricultural machinery, machinery and equipment for livestock farms, measuring instruments, and transfer devices and other mechanisms and assemblies [1].

In agro-industrial complex, transport facilities mean commercial vehicles and tractors. Proper organization of transportation and the use of modern technology determine the main performance indicators of the enterprise: quality and cost of production, labor productivity and social climate in the team. So, transportation costs are $17-38 \%$ and more in the cost of agricultural products. The peculiarity of using transport in agriculture is the transportation of a significant part of cargoes in bulk. Another feature of the transportation of agricultural products is its variability due to temperature, humidity and pressure, and short storage times. A number of requirements are put forward for the carriage of goods in agriculture, depending on the physical and mechanical and agrobiological features of the goods; their total list is 250-300 items.

The degree of utilization of rolling stock is characterized by such indicators as technical availability of the fleet, fleet utilization ratio, rolling stock's capacity utilization rates, loaded mileage proportion, average length of the carriage, average trip distance, contact time, time on duty, cruising speed, operational speed $[1,2]$.

The indicators of the motor transport facilities utilization efficiency include: the running time of rolling stock on the route, the performance of rolling stock, the transport facilities productivity, the cost of a unit of work. The same indicators are used in assessing the use of tractors in transport operations.

The machine and tractor fleet includes agricultural machines for mechanized production processes. Combined harvesters are considered highly specialized machines as they differ by seasonal fluctuation of their utilization. 
The technical and economic level of production directly depends on the availability of machinery and equipment; the indicators of the level are used in planning the development of the material and technical base of agriculture. These indicators are of great importance in the development of the main directions for the development of agricultural policy. In this regard, agricultural engineering industry has an important task to improve the structure and quality of the machine and tractor fleet parameters, that is, increase in engine power, and maneuverability of tractors indicators, and the development of systems of machinery for the production of basic types of products.

A system of machinery provides for a comprehensive mechanization and automation of production processes, reduction in the costs per unit of work and production, and reduces ratio of labour to output for production. The effect of complex mechanization is higher if the technological infrastructure of the specialization corresponds to the scale of the enterprise and to production with the use of advanced technologies. [2, 3]

\section{METHODS}

Modern technologies allow lowering material consumption, energy intensity and labor intensity of production. Mastering of resourcesaving technologies in plant growing takes place in Russia with high rates.

One of the main conditions for the successful implementation of resource-saving technologies is the use of highly efficient agricultural machinery. It is necessary to develop and implement Russian-manufactured combined soil-cultivating and sowing machines and units [4].

It is necessary to create all conditions for the application of modern agricultural technologies, efficient use and purchase of additional equipment in the agricultural sector. The effect of the introduction of new equipment in agriculture is reflected in reduction of labor intensity. However, an important aspect of the issue when acquiring and implementing a new technology is their financial aspect.

One of the features of the relationship between agricultural enterprises and manufacturing plants can be leasing, both in cash and in kind. 
Deliveries of equipment based on leasing play an important role for agricultural enterprises and farm machinery depots having a poor material and technical base. In modern conditions, leasing allows enterprises to solve the problem of acquiring fixed assets. A special leasing fund has been created since 1994 to improve the provision of the agroindustrial complex with machinebuilding products; the fund has been formed at the expense of federal and regional transfers from the budget, and transfers of funds from machinebuilding organizations. Budget allocations are made on an age basis to the Ministry of Agriculture and Food of the Russian Federation. The work is coordinated by the open joint-stock company Rosagrosnab, providing material and technical resources to the enterprises of the agro-industrial complex on the basis of contracts with customers and suppliers.

In accordance with the State program for the development of agriculture and regulation of markets for agricultural products, raw materials and foodstuffs for the acquisition and transfer to agricultural producers by the Open Joint Stock Company
Rosagroleasing under leasing contracts for 2013-2020, the transfer of agricultural machinery in the amount of 2,821 units was envisaged, including grain combines - 468 units, forage harvesters - 38 units, tractors - 1247 units, other equipment - 1068 units $[1,5]$. Information data are factors of the positive development of the agroindustrial machinery market. Information on prices, manufacturers, maintenance and repair is one of the most important components of the effective development of an enterprise as a whole. At present, there are a large number of machinery manufacturers in the agricultural machinery market, both Russian and foreign, while each of them is fighting for buyers who have an opportunity to buy both for their own and for borrowed funds. Therefore, each buyer must have full information about prices, quality and analogues.

\section{RESULTS AND THEIR DISCUSSION}

In this regard, the activities of information and consulting services to promote the creation and development of 
wholesale engineering and technical markets are of particular importance.

Rational use of technical facilities becomes possible with a sufficient number of mechanized personnel and repair bases. The high capital-labor ratio makes it possible to use them more efficiently, and the cost savings are achieved through the cooperation with the use of high-power machines and their short period of use, the organization of timely and highquality maintenance and repair. Farm machinery depots (FMD) can provide technical assistance in carrying out mechanized operations. Abroad, there is a practice on creating agricultural associations for the joint use of machinery. That is, the provision of machinery and equipment, as well as qualified personnel allows optimization of expenditures of enterprises for machinery and its repair, and also provides the opportunity to apply modern technology and the latest methods of work. This experience can be used when creating FMDs in Russia at a new level of production $[6,7]$.

The technical base of agriculture is under the influence of natural and climatic factors and, in connection with this, it differs in the location and specialization of production according to the territorial and agroclimatic characteristics. The most part of Russia's agricultural lands is located in arid regions, in this regard, one of the ways to improve the efficiency of agriculture through technical modernization is land improvement. The development of a reclamation system in agriculture can be helped by investing in the construction of new land reclamation systems, reconstruction and restoration of existing ones.

High capital intensity level of the material and technical base in the agro-industrial complex is affected by the seasonality of the functioning of its elements. That requires additional costs for the storage of machines, formation of seed and feed stocks. Also, production in large areas requires expensive mobile technological infrastructure and mechanisms, the creation of transport and road infrastructure [8].

\section{CONCLUSIONS}

Thus, ensuring the highly effective use of a technological capacity in agriculture implies accounting the 
specifics of the industry, the rational production specialization of rural

\section{REFERENCES}

producers and their needs for equipment and technology, the implementation of strategies for intensification and development of modern progressive forms of organization and machinery use.

\section{SUMMARY}

The role of the technological infrastructure of agriculture in ensuring the economic growth of the agricultural sector is to participate in the increase in the value of the gross national product. The objective of the country's economy should be finding directions and economic justification for ways to improve the state of the agricultural machinery and upgrading of agricultural processes [1,9]. The amount and quality of agricultural products directly depend on the level of technical supply of agricultural industry.

\section{ACKNOWLEDGEMENTS}

The work is carried out according to the

Russian Government Program of Competitive Growth of Kazan Federal University

Subaeva A.K., Zamaidinov A.A. Improvement of Agricultural Machinery Economic Efficiency / A.K. Subaeva, A.A. Zamaidinov // International Vodyannikov, V.T., Sereda, N.A. Reproduction of the technological capacity of agriculture in the conditions of innovative development: monograph / V.T. Vodyannikov, N.A. Sereda. Karavaevo: Kostroma State Agricultural Academy, 2014. - 228 p. Economic Efficiency / A.K. Subaeva, 
Business Management 2015; 9(7): 1770-

1774 ISSN: 1993-5250

Subaeva A.K., Zamaidinov A.A.

Classification of agroindustrial complex technical provision effectiveness indexes/ A.K. Subaeva, A.A. Zamaidinov // JOURNAL OF economics and Economic education research 2016; 4(17): 8-14 ISSN: 15333590

Vodyannikov, V.T., Rubtsov, P.A. Analysis of the technical support for agricultural organizations in the Republic of Mordovia / V.T. Vodyannikov, P.A. Rubtsov. // Bulletin of the Federal State Educational Institution for Higher Professional Education "Moscow State Agroengineering University named after V.P. Goryachkin" - 2013. - №3. - P. 7982.

Vodyannikov, V.T. Methodological and methodical foundations for determining the economic efficiency of technical means / V.T. Vodyannikov // Bulletin of the Federal State Educational Institution for Higher Professional Education "Moscow State Agroengineering
University named after V.P. Goryachkin. " - 2013. - №3. - P. 52-57.

Subaeva A.K., Zamaidinov A.A. Methods of agricultural machinery market regulation / A.K. Subaeva, A.A. Zamaidinov // International Business Management 2015; 9 (7): 1780-1784. ISSN: 1993-5250.

Subaeva, A.K. Economic mechanism of technical support of agriculture (monograph) / A.K.Subayeva // Monograph - Kazan. Publishing house "Brig", 2016.- 216 p 